\title{
A Muslim's Reflections on Saddharamapundariksutra-The Lotus Sutra
}

\author{
Assoc. Prof. Dr. Imtiyaz Yusuf \\ International Institute of Islamic Thought \\ and Civilisation (ISTAC-IIUM)
}

\section{ABSTRACT}

This paper seeks to introduce the general reader to the history of Muslim-Buddhist dialogue, reviewing early instances of interreligious conversation between the two traditions, while also offering a speculative reflection on the Lotus Sutra from an Islamic perspective and highlighting some points of contact between the spirituality of this Buddhist text and the overarching transformative vision of the Qur'an. The author questions the conventional understanding that Islam effectively ignores all religions apart from Judaism and Christianity, noting, for instance, that according to Muhammad Assad, the term kafir-ordinarily translated as "infidel" - actually refers to anyone rejecting spiritual truth, and as such it could not be automatically applied to anyone outside the three Abrahamic traditions. The author also surveys a number of early studies of Buddhism written from an Islamic perspective, such as the work by Abd al-Karim al-Shahrastani (1086-1153 CE), concluding with a striking quote by the mystic Rumi (1207-1273), who claimed that the path to the Mecca and the path to the Buddhist monastery were one and the same. The first section of the paper concludes with the observation that contemporary Islamic scholarship on Buddhism is almost exclusively based on Western sources and on a Western understanding of the religion, while failing to engage original Buddhist texts or to develop a fully Islamic perspective.

In the second section of the paper, the author discusses the Lotus Sutra as a source for wisdom that can be fruitfully read by Muslim scholars and practitioners alike. Relying on the classical Qur'anic notion that all nations received prophets before the coming of Muhammad, the author views the sutra as a channel of divine wisdom, highlighting the parallelism between certain claims of the Mahāyāna tradition — such as the belief in the Buddha nature - and some lesser-known Islamic traditions, such as the belief in the light of Mohammed (nur-Muhammad). The author expresses the hope that IslamicBuddhist dialogue will foster greater interreligious understanding, while underscoring that he does not espouse a perennialist or pluralist theology of religions.

KeYwORDs: Abd al-Karim al-Shahrastani, khifr/kafir, Ibn-al-Nadim, light of Muhammad (nur-Muhammadi), Muslim-Buddhist dialogue, parallelism, perennialism, Qur'an, Rumi 


\section{INTRODUCTION}

I first learned about the Saddharamapundariksutra-The Lotus Sutra in my pro-seminar course on Buddhism at the Department of Religion, Temple University, with Professor Charles Wei-Hsun Fu from the book by William Theodore de Bary, The Buddbist Tradition: In India, China and Japan. ${ }^{1}$ The second time was on my visit to Yuantong Temple, Kunming, China, where in the temple park I saw a woman reading a text. Through my local Chinese student, I asked the lady what was she reading; she replied: The Lotus Sutra. I asked her: for what purpose? She replied that it helped her get through her daily life chores.

My journey of studying about Buddhism began in 1979 during my master's degree in Islamic Studies in the library of the famous Aligarh Muslim University, Aligarh, India, when browsing through library journals I read an article on the early contacts between Islam and Buddhism, I was taken by a shock: did such relations exist? ${ }^{2}$

And as a non-Buddhist who has lived in Thailand for 32 years and now in Malaysia - one being a majority Theravada country and the other a Muslim country with a large Theravada, Mahayana and Vajrayana Buddhist population, and having several Mahayana Buddhist friends as fellow students in Temple University and also my students in Thailand from Vietnam and China and also some scholars I have come to learn about the differences in the attitudes of these Buddhist traditions toward friendship with people of other faiths. While all the Buddhist traditions practice religious tolerance, the Theravadins seem to be circumspect, while the Mahayanists and the Vajrayana are more open to building understanding and dialogue with the Muslims. There are several reasons for this, such as the rise of Buddhist religious nationalists in Sri Lanka and Myanmar; fears about the fast rate of the demographic growth among the Muslim minorities populations; no knowledge about Islam; the rise of Asian Islamophobia ${ }^{3}$; the effects of colonialism and the long colonial and postcolonial eras gap in the building of Muslim-Buddhist understanding in the Muslim countries especially those of Southeast Asia and also elsewhere.

For me, being one of the few Muslims engaging in building Muslim-Buddhist understanding today, my faith standpoint is that while I believe in God, I learn wisdom from the Buddha. This position of mine is based in the Qur'an's inclusive position that historically prophets have been raised in every community who speak and deliver the Truth in their own languages in different parts of the world.

In my view, Buddhism is the most tolerant religions of all religions today, it carries a great message for our age of religious nationalist violence carried out by the extremist members of all religions including Buddhism in Sri Lanka and Myanmar against the religious minorities.

The majority of Muslims are unaware about the teachings of Buddhism just as they are unaware of other Asian religions. Their information about Buddhism is based largely on hearsay or shaped by their viewing of Buddhism through their own lens and views of pre-Islamic Arabian religion of idolatry. They end up viewing Buddhism as being idolatry similar to the views held by eighteenth-century Orientalists. ${ }^{4}$ However, this does not mean that earlier Muslims did not study Buddhism, in fact 
they studied it in more details much before the Europeans, but contemporary Muslims have largely abandoned this rich tradition. I will talk more about it below.

\section{APPROACHING THE ISLAM-BUDDHISM RELATIONS}

My approach to the study of religion is based in the phenomenological and history of religions approaches-it is not polemical.

I want to emphasize that I am not a Perennialist; indeed, I have been described as a parallelist. ${ }^{5}$ I seek to learn and understand the parallels between religions without replacing or substituting between the traditions. I view the religious parallels as unique in themselves - something that can play an important role in helping build understanding and dialogue between religions.

I view religions as parallel lines that do not meet except at a meeting station/ platform and separate again after being enriched progressing toward the next station of the religious journey. I therefore reject the myth of religious or ideological superiority as a philosophical fallacy and religiously mistaken position.

SADDHARAMAPUNDARIKSUTRA-THE LOTUS SUTRA-BRIEF INTRODUCTION FOR THE MUSLIMS

Saddharamapundariksutra-The Lotus Sutra, composed in the first-second centuries of the Common Era, is the most influential and popular of the Mahayana sutras.

Composed of narratives, it teaches two important points: (1) upaya-skill in means and (2) immortality of the Buddha.

In the parable of the burning house .... The three carts symbolize the ŚRATAKA vehicle, the PRATYEKABUDDHA vehicle, and the BODHISATTVA vehicle, while the one cart is the "one vehicle" (EKAYĀNA), the buddha vehicle (BUDDHAYĀNA). This parable indicates that the Buddha's previous teaching of three vehicles (TRIYĀNA) was a case of upāya, an "expedient device" or "skillful method" designed to attract persons of differing capacities to the dharma. In fact, there is only one vehicle, the vehicle whereby all beings proceed to buddhahood. ${ }^{6}$

The twenty-eight chapters in The Lotus Sutra teach that enlightenment is available to all who read, memorize, recite, copy, and explain the Sutra. It does not mention banishment of any being to hell, rather offers hope for all.

\section{HISTORY OF MUSLIM-BUDDHIST RELATIONS}

The current state of interreligious understanding and dialogue in Southeast Asia is that there is mutual misunderstanding or mutual lack of knowledge of each other's religion.

The popular view is that Islam is a religion of violence and Buddhism the religion of peace. ${ }^{7}$ And in the case of political conflicts between them, both the Muslims and the Buddhists take exclusivist position, each community thinks that only if the other understood them there will be peace. 
It is time to overcome this mutual reciprocal dialogue of ignorance and related ethnoreligious conflicts in Southeast Asia in which both the communities are betraying the essential teachings of Islam and Buddhism, that is, mercy and compassion as the sources of religious humanism. Otherwise, it seems that both the Muslims and the Buddhists throw out the Prophet Muhammad and the Buddha-the founders of the world religions just as one throws the baby with the bathwater. Such popular mutual views are huge obstacle blocks in in the path of building Muslim-Buddhist interreligious understanding.

The present mutual religious ignorance between the Muslims and the Buddhists is becoming increasingly insurmountable.

In spite of such state of affairs, there are also genuine efforts at building and managing interreligious relations between the Buddhists and the Muslims. Indeed, there are two types of interreligious ignorance. One is when the followers of one religion do not know the other religions. The other is when one does not want to learn the religion of others.

Since Islam is a Semitic religion, it had no problems in relating to and dialoguing with other Semitic religions of Judaism and Christianity. Several Muslim scholars have written about the relations between Islam and Semitic religions, which is well documented. In fact, Islam's dialogue with a Semitic religion is a continuing dynamic process mostly conducted in the West and the Middle East and also in Asia and Africa. However, being a Semitic monotheistic religion, Muslims have had an ideational and theological difficulty in relating to Asian and African religions.

The majority of Muslim scholars and laymen have often interpreted Asian and African religions from an Arabian/Semitic perspective on polytheism and have simply written off Asian and African religions as being or amounting to shirkpolytheism and their adherents as kafir-nonbelievers in monotheism without understanding the philosophical dimension of Hindu monism ${ }^{8}$ or Buddhist nontheism ${ }^{9}$ or of African religions. Exceptions being the works of al-Biruni, ${ }^{10}$ al-Shahrastani, and Muhammad Hamidullah. ${ }^{11}$

Such a Muslim position toward Asian religions is adopted without applying the tools of historical criticism nor philosophical analysis. Muhammad Asad, a translator and an exegete of the Qur'an, comments that the meaning of the terms kufr and kafir in the Qur'an is determined by the meaning these terms had in the Arabic language during pre-Islamic times. Their meaning cannot be equated to "unbeliever" or "infidel" in the restricted sense of referring to one who rejects the doctrine of the Qur'an and the teachings of Muhammad, as is being done by Muslim theologians of the postclassical times and also by Western translators of the Qur'an. He remarks that, "a kafir is 'one who denies [or "refuses to acknowledge"] the truth' in the widest, spiritual sense ... irrespective of whether it relates to a cognition of the supreme truthnamely, the existence of God-or to a doctrine or ordinance enunciated in the divine writ, or to a self-evident moral proposition, or to an acknowledgement of, and therefore gratitude for, favors received."12

The term shirk means the ascribing of divinity to anything besides God and "is not confined to a worship of other "deities" but implies also the attribution of divine or 
quasi-divine powers to persons or objects not regarded as deities: in other words, it embraces also saint worship and so on." It is "overstepping the bounds of truth," which is common teaching of all religions, monotheists or not. ${ }^{13}$ Thus, in the case of Buddhism, it would imply overstepping the Dhamma - the teachings of the Buddha.

Though Islam and Buddhism are different doctrinally, they have historically come into contact first in Central Asia, ${ }^{14}$ later South Asia, and Southeast Asia. ${ }^{15}$

The history of relations between Islam and Buddhism is a long one. ${ }^{16}$ Indeed, religious encounter between Islam and Buddhism is as old as Islam itself. ${ }^{17}$ The first encounter between Islam and ashab al-Bidada, or the Buddhist community, took place in the middle of seventh century in the regions of East Persia, Transoxiana, Afghanistan, and Sindh. ${ }^{18}$ Historical evidences suggest that early Muslims extended the Qur'anic category of abl al-Kitab (people of the book or revealed religion) to include the Hindus and the Buddhists. ${ }^{19}$

During the second century of Islam or the eighth century CE, Central Asian Muslims translated many Buddhist works into Arabic. We come across Arabic titles such as Bilawar wa Budhasaf and Kitab al-Budd, as evidences of Muslims learning about Buddhism. ${ }^{20}$

In spite of being aware of the idol worship of the Buddha, Ibn al-Nadim (d. 995 $\mathrm{CE})$, the author of al-Firbist, comments that:

These people (Buddhists of Khurasan) are the most generous of all the inhabitants of the earth and of all the religionists. This is because their prophet Budhasaf (Bodhisattva) has taught them that the greatest sin, which should never be thought of or committed is the utterance of "No". Hence they act upon this advice; they regard the uttering of "No" as an act of Satan. And it is their very religion to banish Satan. ${ }^{21}$

There are evidences of Buddhist survivals in the succeeding Muslim era of this region in Central Asia, such as the Barmak family of Buddhist monks who played a powerful administrative role in the early Abbasid dynasty. The Abbasids ruled from Baghdad during 750-1258 CE, governing most of the Islamic world. The Barmakids controlled the Buddhist monastery of Naw Bahar near Balkh in addition to other Iranian monasteries. ${ }^{22}$

There was also the continuation of several Buddhist beliefs and practices among the Muslims of Central Asia. For example, the Samanid dynasty, which ruled Persia during the ninth and tenth centuries, invented and modeled the madrasab or Muslim religious schools that were devoted to studies in the Islamic religious sciences after the Buddhist schools in eastern Iran. ${ }^{23}$ A similar case may be the pondoks or pasenterensthe Muslim religious schools of Southeast Asia.

The second encounter between Islam and Buddhism took place in South and Southeast Asia beginning around twelfth-sixteenth centuries. In case of India, there is a common misunderstanding that Islam wiped out Buddhism through conversion and persecution. ${ }^{24}$ Regarding this misunderstanding, Islamic studies scholar Marshall Hodgson remarks: 
Probably Buddhism did not yield to Islam so much by direct conversion as by a more insidious route: the sources of recruitment to the relatively un-aristocratic Buddhism - for instance, villagers coming to the cities and adopting a new allegiance to accord to their new status - turned now rather to Islam than to an outdated Buddhism. The record of the massacre of one monastery in Bengal, combined with the inherited Christian conception of Muslims as the devotees of the sword has yielded the widely repeated statement that the Muslims violently "destroyed" Buddhism in India. Muslims were not friendly to it, but there is no evidence that they simply killed off all the Buddhists, or even all the monks. It will take much active revision before such assessments of the role of Islam, based largely on unexamined preconceptions, are eliminated even from educated mentalities. ${ }^{25}$

The third meeting between Islam and Hindu-Buddhist civilization took place in Indonesia, Malaysia, and Thailand; it was a sort of dialogue between the monotheistic, monistic, and nontheistic religious traditions. Islam arrived here in its mystic orientation, which was shaped by the Persian and Indian traditions of Sufism. ${ }^{26}$

The Muslims who brought Islam first to Indonesia and then to Malaysia and southern Thailand in the twelfth-fifteenth centuries were the traders and Sufi mystics. In religious terms, it was meeting between Hindu concept of mokșha"liberation" through the notion of monism, the Buddhist concept of nirvana, "passing away" of greed hatred and delusion, or bodhi, "enlightenment" through the realization of sunyata-(emptiness), and the Islamic concept of fana, "passing away" of one's identity through its mergence in Universal being as presented in the monotheistic pantheism of the Sufis. Gradually there emerged a hybrid culture, particularly in Java and in other parts of Southeast Asia, resulting in an Islam that was mystical, fluid, and soft and a spiritualism that is peculiar to the region. ${ }^{27}$

Today, Islam coexists with Hinduism and Buddhism in South and Southeast Asia, the state of this relationship is diverse depending on the context of the regional and local histories of the various countries in these regions.

\section{MUSLIM SCHOLARS OF BUDDHISM}

Alexander Berzin is absolutely correct in saying that reducing the study of the relation and interaction between Islam and Buddhism to Sufism (Islamic mysticism) is insufficient, limiting, and problematic. It is necessary to expand the study of Islam and Buddhism in order to find common points between these two religions, to obtain a more comprehensive understanding of Islam-Buddhism relations and to build religious harmony and global civilization. ${ }^{28}$

Early Muslim scholars of history and comparative religion such as Abu Ja'far Muhammad ibn Jarir al-Tabari (839-923 CE), who was born in Amul in Tabaristan, northern Persia, mention that Buddha's idols were brought from Kabul, Afghanistan, to Baghdad in the ninth century and sold in the Makh mosque in the market of the city of Bukhara in present Uzbekistan. ${ }^{29}$ 


\section{Early Muslim Pioneers of Study of Buddhism in the Eleventh-Fourteenth Centuries}

Abd al-Karim al-Shahrastani (1086-1153 CE), an influential Persian historian of religions and a historiographer and the author of "Kitab al-Milal wa al-Nibal" (lit. The Book of Religious Parties and Schools of Philosophy) was one of the pioneers of an objective and philosophical approach to the study of religions. As per Eric J. Sharpe, "the honor of writing the first history of religion in world literature" belongs to alShahrastani, he described and systematized all the religions of the then known world as far as China. ${ }^{30}$

According to al-Shahrastani, the Qur'anic perspective of the universal institution of prophethood enables the Buddha to be counted among prophets that have appeared in different places and different languages.

Rashid-al-Din Hamadani (1247-1318 CE), a Persian statesman, was a Jewish convert to Islam. As a historian, he authored a universal history, Jami altawarikh (Compendium of Chronicles). The book has been referred to as the "first world history." He wrote a detailed life story of the Buddha. He aimed at making Buddhism accessible to Muslims. ${ }^{31}$

Hafiz-e Abru (died June 1430 CE), a Persian historian working at the courts of Timurid rulers of Central Asia, was an author of many historical and historicogeographical works in Persian commissioned by Shahruk, the Timurid ruler of the fifteenth century

His book Majma' al-tawarik is a universal history up to the year 830/1426, written for Shahruk's son Baysongor.

The first three sections concern with the pre-Islamic prophets, Mohammad, and the caliphate and the dynasties contemporaneous with the Abbasids and the Mongols up to the death of Abu Said.

\section{Muslim Poets Reflect on the Buddha and Buddhism}

Similarly, Islam's two famous personalities, Rumi, the mystic, and Muhammad Iqbal, the famous poet-philosopher from the Indian subcontinent, have lauded the religious message of the Buddha.

Rumi (1207-1273 CE) in his poem Kulliyat-e Shams-e Tabrizi, 302, sees spiritual equality between the sacred sites of Mecca and Butkhane-a Buddhist monastery.

On truth's path, wise is mad, insane is wise.

In love's way, self and other are the same.

Having drunk the wine, my love, of being one with you,

I find the way to Mecca and Butkhane (Buddhist monastery) are the same.

Rumi, Kulliyat-e Shams-e Tabrizi, 302

Muhammad Iqbal (1877-1938 CE) dedicated two of his poems to the Buddha.

In the poem titled: "Nanak" in "Bang-e-Dara," he calls the teaching of the Buddha as a message of truth and humanism that was lost on Indian Brahmins while it flourishes outside India today. 
The nation could not care less about Gautama's message-

It did not know the price of its unique pearl!

Poor wretches! They never heard the voice of truth:

A tree does not know how sweet its fruit is.

What he revealed was the secret of existence,

But India was proud of its fancies;

It was not an assembly-hall to be lit up by the lamp of truth;

The rain of mercy fell, but the land was barren.

Alas, for the shudra India is a house of sorrow,

This land is blind to the sufferings of man.

The Brahmin is still drunk with the wine of pride,

In the assembly-halls of foreigners burns Gautama's lamp.

But, ages later, the house of idols was lit up again-

Azar's house was lit up by Abraham!

Again from the Punjab the call of monotheism arose:

A perfect man roused India from slumber.

Muhammad Iqbal, "Nanak" in Bang-e-Dra-143

In his another poem title, Taseen-e-Gautam (Gautam Budh Ki Taleemat-The Buddha's Teachings in the Javed Nama-12), he reflects as follows:

Ancient wine and youthful beloved are - nothing;

for men of true vision the houris of Paradise are - nothing.

Whatever you know as firm and enduring passes away,

mountain and desert, land, sea and shore are - nothing.

The science of the Westerners, the philosophy of the Easterners

are all idol-houses, and the visiting of idols yields - nothing.

Think upon Self, and pass not fearfully through this desert, for you are, while the substance of both worlds is - nothing.

On the road which I hewed out with the point of my eyelash station and caravan and shifting sands are - nothing.

Transcend the unseen, for this doubt and surmise are nothing; to be in the world and to escape from the world - that is. Something!

The Paradise that some God grants unto you is nothing; when Paradise is the reward of your labours - that is something.

Do you seek repose for your soul? The soul's repose is nothing; the tear shed in sorrow for your companions - that is something. The wine-drenched eye, the temptress glance and the song are all fair, but sweeter than these - there is something.

The cheek's beauty lives for a moment, in a moment is no more; the beauty of action and fine ideals - that is something. ${ }^{32}$

In my view as a Muslim academic interested in the history of religion, Islam and Buddhism represent the teachings of two great religious founders, namely the 
Prophet Muhammad as a rasul-messenger, and the Buddha as the guru - the teacher. Both represent the wisdoms of Islam and Buddhism. ${ }^{33}$

The current rise of Muslims-Buddhists violent conflicts and tensions in Myanmar, Sri Lanka, and a century-old conflict in southern Thailand has caught world attention. It is raising questions about the relation between Buddhism and violence and also about the history and nature of Muslim-Buddhist relations and understanding over centuries. A relationship that started with the beginning of Islam and has both positive and negative features.

Unfortunately, relations and attempts at mutual learning between Muslims and Buddhists have declined with the decline of the age of Islam and the rise of the colonial West. ${ }^{34}$ Since the colonial era until today, Muslims and Buddhists have coexisted as separate religious-sociocultural communities with ethnic accentuations taking on religious colorings. This era is also marked by mutual ignorance about the deep teachings of both religions, while superficial understandings thrive causing conflicts and violence whose roots lie more in the area of political-economy than religion.

Southeast Asia is the only part of the world today where Islam and Buddhism coexist in direct religious, cultural, and political contact. Thus, while the rest of the Muslim world may ignore Buddhism, the Muslims of Southeast Asia cannot afford to do so. In the Association of Southeast Asian Nations region, Muslims and Buddhist coexist in large numbers, namely 42 percent and 40 percent, respectively.

In the 900-year history of Islam-Buddhism coexistence in Southeast Asia, though early Islam was syncretic in terms of culture and not theology (still continues to be so in some quarters), both of these world religions have acquired ethnic identities. As far as I know today there is no one Southeast Asian Muslim scholar of Buddhism and vice versa. Rather, Muslim-Buddhist understanding of Islam and Buddhism today unlike in the past is taking place via Conscientia Orientalis-knowledge as shaped by Orientalist consciousness rather than Asian consciousness. The majority of Muslim writers on Buddhism in the modern age have learned Buddhism from Western sources and have adopted and applied Western definitions such as nihilism, polytheism, and so on in understanding Buddhism rather than studying Buddhism from its own sources and its own teachers. Such a state of knowledge ends up in dialogue of ignorance.

Some contemporary Muslim scholars have applied monotheistic/polytheistic religious definitions taken from the era of pre-Islamic Arabian polytheist religion to define and describe Buddhism. They erroneously classify Buddhism as polytheism. ${ }^{35}$ While the fact of the matter is that the Buddha rejected his own deification and the Buddhists do not worship him as God.

On the other hand, Muslims and Buddhists in Southeast Asia are also often unaware that they share many religious expressions/terms such as agamal sasanareligion; puasa fasting; hari raya - day of celebration and even personal names due to the mixing of Sanskrit, Pali, and local Indo-Malay languages.

\section{THE MUSLIM'S STRUGGLE WITH CASE BUDDHISM AS NONTHEISTIC RELIGION}

The nontheist nature of Buddhism creates theological and intellectual problems for the Muslims and the monotheists, who cannot conceive of a nontheist religion. 
As a result, the theist and nontheist dwell in the myth of religious superiority of their respective religions, both sides are not open to understand that Ultimate Reality has been interpreted in a variety of ways. Thus, while accepting equality of human beings is easy, accepting equality of religions is a difficult task. This can only happen if both the theists and nontheists are ready to transcend to higher levels of religious understanding and consciousness.

Humanity has experienced Ultimate Reality in three ways, that is, from "outside" as in the cases of Abraham, Moses, Jesus, Muhammad, and other Semitic prophets; from "within" as in the case of Indian religions of Hinduism, Jainism, and Buddhism; and through a medium as in the case of Shamanistic and African religions. In this sense, the Buddha encountered Ultimate Reality from within, that is, he attained nirvana through enlightenment (bodhi). In Mahayana Buddhism, this enlightenment was interpreted as the insight into universal Sunyata ("emptiness" or "nothingness"). The Buddhist concept of Sunyata is closer to the Islamic notion fana fillab-dissolution in Allah as the final stage on the journey of return to Allah-the Unseen:

This is the Scripture whereof there is no doubt, a guidance unto those who ward off (evil). Who believe in the unseen, and establish worship, and spend of that We have bestowed upon them; (Qur'an 2:2-3)

All that lives on earth or in the heavens is bound to pass away but forever will abide thy Sustainer's Being, full of majesty and glory. (Qur'an 55:26-27) There is no deity save Him. Everything is bound to perish? save His [eternal] Self. (Qur'an 28:88)

I see parallels between Sunyata and Fana fillah in their self-uniqueness.

With the risk of being accused of generalizing, I see philosophical compatibility between theistic and nontheistic views of Ultimate Reality as defined by the concepts of Elohim/Yahweh, Lord Jesus, ${ }^{36}$ Allah, and Dharma.

The messages of the Buddha and Muhammad are the messages of Truth: There is a parallel between the message of sunyata (emptiness) as based on the doctrine of the eternal Dharma - universal order/natural law and on liberation through enlightenment, the attainment of nirvana, and Islam's message of tawbid - moralistic monotheism attained through waby-revelation to the Semitic prophets.

The messages of Islam and Buddhism are messages of liberation from dukkhasuffering, and zulm - injustice. The Buddha was prompted by witnessing the "four sights" - of an old man, a sick man, a corpse, and a monk representing suffering and possibility of attaining liberation to leave the life in the palace and Muhammad by witnessing the practice of tribal rivalries, female infanticide, existence of slavery and hedonism, and his retreats to the meditation and contemplation seeking an answer to these existential questions.

In the case of Islam, salvation is based on belief in Allah/God as the Absolute, as nonpersonal being, as mono-theos as revealed to Muhammad, a belief accompanied by performing good deeds and good conduct. 
The Muslim mystic, Frithjof Schuon, describes Buddha's Nirvana as a super-rational unveiling of mercy about how to deal with the problem of suffering. ${ }^{37}$ In Buddhism, the Absolute is of "a cosmic and anonymous character ... Nirvanic Grace" projected through the Buddhas. In theist Islam, the divine "is cosmic manifestation as Ontological cause and anthropomorphic personification." ${ }^{38}$ Understanding this will help in building cooperation between the two religions. The monotheistic concept of God in Islam, though expressed in anthropomorphic language for the sake of human comprehension, is essentially impersonal.

Islam and Buddhism are essentially messages of liberation in spite of their metaphysical variance.

\section{IS ISLAM GOD'S ONLY CHOSEN RELIGION?}

The majority of Muslims opine that Islam is the only religion preferred by God and will prevail over other religions. This Muslim view is based on a literal reading of the following verses in the Qur'an.

Behold, the only [true] religion in the sight of God is Islam. (Qur'an 3:19) And whoso seeks as religion other than the Surrender to God (Islam) it will not be accepted from him, and he will be a loser in the Hereafter. (Qur'an 3:85)

Such verses demand to make a distinction between philosophical Islam, which refers to as belief in Unseen God/Ultimate Reality and practice of righteous living, and the institutionalized Islam of history of the post-Muhammad era.

While there are other verses of the Qur'an that point toward recognition and respect for religious pluralism.

The apostle (Muhammad) and the believers with him, believe in what has been bestowed upon him from on high by his Sustainer: they all believe in God, and His angels, and His revelations, and His apostles, making no distinction between any of His apostles; and they say: "We have heard, and we pay heed. Grant us Thy forgiveness, $\mathrm{O}$ our Sustainer, for with Thee is all journeys' end! (Qur'an 2:285) And of His signs is the creation of the heavens and the earth and the diversity of your tongues and colors. Surely there are signs in this for the learned." (Qur'an 30:22)

For each We have appointed a divine law and a traced out way. Had Allah willed He could have made you one community. But that He may try you by that which He hath given you (He hath made you as ye are). So vie one with another in good works. Unto Allah ye will all return, and He will then inform you of that wherein ye differ. (Qur'an 5:48)

And for every nation there is a messenger. And when their messenger cometh (on the Day of Judgment) it will be judged between them fairly, and they will not be wronged. (Qur'an 10:47)

And verily We have raised in every nation a messenger, (proclaiming): Serve Allah and shun false gods. Then some of them (there were) whom Allah 
guided, and some of them (there were) upon whom error had just hold. Do but travel in the land and see the nature of the consequence for the deniers! (Qur'an 16:36)

Some of these Messengers are mentioned in the Qur'an by Allah and some of them are not as the Qur'an says:

And, indeed We have sent Messengers before you $\left(\mathrm{O}\right.$ Muhammad $\left.{ }^{(\mathrm{P})}\right)$; of some of them We have related to you their story and of some We have not related to you their story, and it was not given to any Messenger that he should bring a sign except by the Leave of Allah. So, when comes the Commandment of Allah, the matter will be decided with truth, and the followers of falsehood will then be lost. (Qur'an 40:78)

\section{SADDHARAMAPUNDARIKSUTRA-THE LOTUS SUTRA}

Nikkyo Niwano has elaborately clarified the doctrinal developments in Japanese Buddhism in which the Saddharamapundariksutra-The Lotus Sutra occupies the supreme place among the sutras.

Saddharamapundariksutra-The Lotus Sutra contains the main teachings or the very heart of the Sakyamuni's teachings about:

1. the true nature of the universe and of human beings;

2. how to live one's life and relate with others; and

3. the ever presence of the Buddha and the human beings' possession of the buddha-nature - the potential for enlightenment - all can attain Buddhahood, if they strive for it. ${ }^{39}$

Niwano also elucidated the place of Saddharamapundariksutra-The Lotus Sutra amid the different Buddhist schools of Japan since the Nara period (710-94) onward. Incidentally, Islam appeared during the same period during the seventh century in Arabia when Muhammad was appointed as the last prophet of Allah in 622 CE with the beginning of revelation of the Qur'an. ${ }^{40}$

For me the most significant part of Nikkyo Niwano's introduction was the clarification of the differences between the rise of the Nembutsu-Pure Land Buddhism of Honen and Shinran, which relies exclusively on the chanting of the nembutsurecitation of the Name of Amida Buddha-Namu-amida-butsu-to acquire merit for birth into the Pure Land; the elitist Zen Buddhism, which connected meditation and liberation; and the teaching of Nichiren for whom, "the only way to achieve (salvation for people of all classes) is to be found in the practice of the teachings of the Lotus Sutra and the way to salvation should progress from understanding to faith and faith to practice." ${ }^{41}$ Thus, salvation lies in valuing, receiving, keeping, chanting, and practicing the Lotus Sutra and its parables. ${ }^{42}$

What interested me the most about the Lotus Sutra is its respect for human dignity of all and availing of salvation for all marked by the absence of the concept of $\sin$. 
And also the mental freeing from the daily delusions of life; making the world a better and a beautiful place, which in the Qur'an contained in the prayer:

But there are among them such as pray, "O our Sustainer! Grant us good in this world and good in the life to come, and keep us safe from suffering through the fire” (Qur'an 2:201)

In this way, the Qur'an and the Lotus Sutra when understood comprehensively and as paralleled texts emphasize on belief, faith, and wholesome practice in which politics is one and not the main aspect of religious life and thought. ${ }^{43}$

\section{SADDHARAMAPUNDARIKSUTRA-THE LOTUS SUTRA-A MUSLIM'S REFLECTIONS}

In his famous book, "What is Scripture" from a comparative perspective, Wilfred Cantwell Smith opined that in the modern age and with rise of historical critical methods, scriptures live side by side. It is difficult to claim the absoluteness of one over others and there are religious traditions where oral religious tradition is primary and the scriptures are absent. ${ }^{44}$

Yet, religious texts play an important role in the lives of the people, for religion is a human condition. In this case, The Lotus Sutra and the Qur'an play central roles in the lives of the Buddhists and Muslims in our age of digital disruptions and troubled culture as we seek the answer to the question about what it means to be human.

The Qur'an and The Lotus Sutra are paralleled in the ways both the texts are treated in history. Over 1440 years, the teachings of the Qur'an and its parables as examples for practicing a life of rectitude have been preserved as an intact scripture, which has been memorized, is chanted every day in rituals and daily practices.

The memorizing, chanting, writing, practicing the teachings of the Qur'an are valued as the means of gaining merit and ways to salvation. ${ }^{45}$

In the light of the Qur'anic teaching that God has sent prophets in every place and in every language before Prophet Muhammad, which as per the Muslim tradition, amount to a total of 124,000 prophets, the Qur'an and Muslims have no issue in accepting the scriptural status of The Lotus Sutra as a religious text of the Buddhist in spite of the differences in their views about the ways of producing religious texts/scriptures.

The early Muslims also accorded the status of abl al-kitab (People of the Book) to the Hindus and Buddhists (which was earlier assigned to only the Jews and Christians) whom they met for the first time in India. ${ }^{46}$

And never have We sent forth any apostle otherwise than [with a message] in his own people's tongue, so that he might make [the truth] clear unto them; (Qur'an 14:4)

Hence, I read The Lotus Sutra parables with this Qur'anic worldview and spirit. I will only present some of the striking parallel wisdom teachings from The Lotus Sutra, which are concordant with the message of the Qur'an. 
I am not saying that they are similar or in agreement but are in harmony with the Qur'an. Here I benefit from Paul Ricoeur's concepts of "discordant/concordance" as presented in his monumental work, Time and Narrative. ${ }^{47}$ It means using language to make a sense of human action and time, which "refigures physical events as narrative events, events which make sense because they tell what happens in a story or history" in reference to lived time, which has a past and a future-and cosmic time whereby the "Narrative interweaves these two perspectives on time into human time without ever fully resolving the aporias raised by thinking about time in time." 48

In the religious discourse, be it limited to the Biblical tradition or other religious traditions, it "enables the use these texts both to identify and to legitimate themselves through a kind of hermeneutic circle. That is, such texts are sacred to traditions which take them as legitimating the tradition founded on these texts, something discovered through their reading and interpreting of such texts." 49

As I read The Lotus Sutra, I came to learn and appreciate it as Buddha's wisdom teachings sacred to the Buddhist traditions and as paralleled and not similar/agreement with Islam. I am not looking for Buddhism in Islam, nor Islam in Buddhism, but engaging in the task of discovering the sacred as interpreted and understood in both the Islamic and Buddhist traditions.

THE LOTUS SUTRA AND THE QUR'AN PARALLELS: BUDDHA'S ELUCIDATION OF THE GREAT LAW TO THE GRAND ASSEMBLY AND THE LAST MESSAGE OF MUHAMMAD

1. The Lotus Sutra-The Introduction

After the Buddha had preached the Lotus, causing all the assembly to rejoice, on that very same day he announced to the assembly of heavenly and human beings, "I have already expounded for you the meaning of the true entity of all phenomena.

Now when midnight comes

I will enter nirvana.

You must strive with all your hearts and remove yourselves from indulgence and laxity, it is very difficult to encounter a Buddha. you meet one once in a million kalpas." When the children of the World-Honored One heard that the Buddha was to enter nirvana, each one was filled wit sorrow and distress, wondering why the Buddha should so quickly seek extinction. The sage lord, king of the Law, comforted and reassured the countless multitude, saying, "when I enter extinction you must not be concerned or fearful!" 50 
2. Before his death, the Buddha had not named a successor, but instead told his followers that from then on, "Whatever Dharma \& Vinaya I have pointed out \& formulated for you, that will be your Teacher when I am gone."

3. The Last Sermon of Prophet Muhammad:

This sermon was delivered on the ninth day of Dhul-Hijjah, 10 A.H. (623 CE) in the Uranah valley of Mount Arafat in Mecca. It was the occasion of annual rites of Haj. It is also known as the Farewell Pilgrimage.

After praising and thanking Allah, the Prophet (p.b.u.h.) began with the words:

"O People! Lend me an attentive ear, for I know not whether after this year I shall ever be amongst you again. Therefore, listen carefully to what I am saying and take these words to those who could not be present here today."

"O People! just as you regard this month, this day, this city as sacred, so regard the life and property of every Muslim a sacred trust. Return the goods entrusted to you to their rightful owners. Hurt no one so that no one may hurt you. Remember that you will indeed meet your Lord, and that he will indeed reckon your deeds."

"Beware of Satan, for the safety of your religion. He has lost all hope that he will be able to lead you astray in big things so beware of following him in small things."

"O People it is true that you have certain rights with regard to your women but they also have rights over you. Remember that you have taken them as your wives only under Allah's trust and with His permission. If they abide by your right then to them belongs the right to be fed and clothed in kindness. Do treat your women well and be kind to them for they are your partners and committed helpers. And it is your right that they do not make friends with any one of whom you do not approve, as well never to be unchaste."

"O People! listen to me in earnest, worship Allah, say your five daily prayers, fast during month of Ramadan, and give your wealth in Zakat. Perform Haj if you can afford it."

"All mankind is from Adam and Eve, an Arab has no superiority over a non-Arab nor a non-Arab has any superiority over an Arab; also a White has no superiority over a Black nor a Black has any superiority over a White except by piety and good action. Learn that every Muslim is a brother to every Muslim and that the Muslims constitute one brotherhood. Nothing shall be legitimate to a Muslim which belongs to a fellow Muslim unless it was given freely and willingly."

"Do not therefore do injustice to yourselves. Remember one day you will meet Allah and answer your deeds. So beware, do not astray from the path of righteousness after I am gone."

"O People! No Prophet or apostle will come after me and no new faith will be born. Reason well, therefore O People! and understand words that I convey to you. I leave behind me two things, the Qur'an and the Sunnah and if you follow these you will never go astray."

"All those who listen to me shall pass on my words to others and those to others again; and may the last ones understand my words better than those who listen to me directly."

"O Allah, be my witness, that I have conveyed your message to Your people." 
As part of this sermon, the prophet recited to them a revelation from Allah, which he had just received and which completed the Qur'an, for it was the last passage to be revealed:

This day the disbeliever's despair of prevailing against your religion, so fear them not, but fear Me (Allah)! This day have I perfected for you, your religion and fulfilled My favour unto you, and it hath been My good pleasure to choose Islam for you as your religion. (Qur'an 5:3) $)^{51}$

THE TATHAGATA AND NUR MUHAMMADI-UPAYA/HŌBEN-EXPEDIENT MEANS AND SUNNAH-THE EXAMPLE OF MUHAMMAD

Sometime back I had published a paper titled, "Dialogue between Islam and Buddhism Through The Concepts of Tathagata and Nur Muhammadi" International Journal of Buddhist Thought and Culture, vol. 5 (2005): 103-114 in which I delved on how Muhammad's becoming of a prophet and the Buddha's Nirvana enabled the Buddha to become the Tathagata- "one who has gone thus" and Muhammad to become the embodiment of Nur Mubammadi-light of Muhammad-both becoming liberated beings who after their religious experience worked for liberation of humanity from suffering and injustices. They both become to serve as religious architypes of compassion and mercy. Without seeking to Buddhicize Islam or Islamize Buddhism, the purpose was to show how motifs drawn from religious phenomena can serve as mediums for building an understanding and dialogue between the two religions and their societies.

And as bearers of charisma, the Buddha and Muhammad, both of whom were able to uncover the essential nature of being, became models or avenues worthy of emulation and serve as bridges for Muslim-Buddhist dialogue. The Qur'an describes Muhammad as only a human and a messenger entrusted with the guidance of the people (Qur'an 6:50; 25:8, 22) and the Qur'an also contains symbolic references to Muhammad as the light (Qur'an 5:15) and sirajan munirab-one who summons to God by His leave and as a light-giving beacon. (Qur'an 33:46).

The luminous nature of Muhammad serves as a model for Muslims about the state of fitrab - the natural disposition of humanity in relation to God, that is, of God as the creator $(r a b b)$ and human being as the servant $(a b d)$.

Muhammad through his Sunnab-living example revealed the true state of being, which has been obscured through human confusion and ignorance, attachment to ego, and a materialistic world view. And since then, Muhammad's revelation and his Sunnab or example have become reference points for the Muslims. In other words, the Sunnab or example of Muhammad is the parallel example of Upayalbōbenexpedient means in Islam.

Just as Upayalbōben refers to Buddhist paths of liberation or "skill in means" in which conscious action, methods, or techniques are used to gain enlightenment.

The notion of skillful means is adumbrated in the famous "simile of the raft" from the ALAGADDŪPAMASUTTA, where the Buddha compares his teachings to a makeshift raft that will help one get across a raging river to the opposite 
shore: after one has made it across that river of birth and death to the "other shore" of NIRVĀNAA, the teachings have served their purpose and may be abandoned; in one sense, therefore, all his teachings are merely an expedient. The notion of skill-in-means also suggests that the Buddha intentionally fashions different versions of his teachings to fit the predilections and aptitudes of his audience. $^{52}$

The Sunnab of Muhammad is the way for the Muslim to practice Islam in the world by emulating Muhammad's example as a path to salvation.

Professor Fazlur Rahman talks about two types of Sunnab- "Nabawi sunna" being the behaviours and action of Muhammad as the "ideal sunnab" and "living sunnab" being its emulation by the Muslims as individuals and as a community that seeks to practice the ways of Muhammad in every aspect of life as derived from the ideal Sunnah. In other words, the practical and living dimension of Islam as a religion and a worldview. ${ }^{53}$

With above concepts of Upayalbōben and Sunnah in the background, I want to reflect on the chapter 2-Expedient Means of The Lotus Sutra and its teachings about following topics:

\section{One Vebicle}

That the words of the various Buddhas do not differ in regard to enabling the people to escape from suffering and attain nirvana and that the three vehicles of shravaka -voice hearer; pratyekabuddha - who gains enlightenment by himself and bodhisattva are one. ${ }^{54}$

The Buddha, through the power of expedient means, has shown them the teachings of the three vehicles prying living beings loose from this or that attachment and allowing them to attain release. ${ }^{55}$

The above teaches about the importance of intrareligious tolerance as the way of peaceful religiosity from which other religions can learn this missing dimension of theirs.

\section{Inclusive Salvation for All}

The door of Buddha wisdom is open for all and that is the reason for the Buddhas to appear to teach wisdom.

The Buddhas, the World-Honored Ones, wish to open the door of Buddha wisdom to all living beings, to allow them to attain purity. That is why they appear in the world. They wish to show the Buddha wisdom to living beings, and therefore they appear in the world. They wish to cause living beings to awaken to the Buddha wisdom, and therefore they appear in the world. They wish to induce living beings to enter the path of Buddha wisdom, and therefore they appear in the world. Shariputra, this is the one great reason for which the Buddhas appear in the world. ${ }^{56}$ 
Similarly, the Qur'an teaches that God does not burden any human being beyond his or her ability. Hence, the prayer to God for mercy and compassion.

God does not burden any human being with more than he is well able to bear: in his favour shall be whatever good he does, and against him whatever evil he does. "O our Sustainer! Take us not to task if we forget or unwittingly do wrong! "O our Sustainer! Lay not upon us a burden such as Thou didst lay upon those who lived before us! O our Sustainer! Make us not bear burdens which we have no strength to bear! "And efface Thou our sins, and grant us forgiveness, and bestow Thy mercy upon us! Thou art our Lord Supreme: succour us, then, against people who deny the truth!” (Qur'an 2:285-286)

\section{BUDDHAS AND PROPHETS-LIBERATORS OF HUMANITY}

In the Indian and Semitic traditions, there are two different types of religious personalities - the Buddhas and the Nabis/Rasuls, both of whom are human carriers of sacred teachings and messages to their folks. And both have a long tradition of histories.

Buddhism and Islam hold that human beings have always engaged in search for meaning.

- There are Buddhas and prophets before historical Buddha and Muhammad.

- Qur'an mentions twenty-five prophets, including Muhammad from the Semitic tradition and institution of prophethood as a universal phenomenon:

Ghafir (The Forgiver)

And indeed, [O Muhammad], We have sent forth apostles before your time; some of them We have mentioned to thee, and some of them We have not mentioned to thee (Qur'an 40: 78; cf. 4: 164).

And never have We sent forth any apostle otherwise than [with a message] in people's own tongue.... (Qur'an 14: 4)

The Qur'anic concept of risalah, or prophethood, offers an analogue with the Buddhist concept of "Buddha" in certain ways.

Buddhas appear in different epochs to teach the path to nirvana.

The messages of the Buddha and Muhammad are the messages of Truth about:

Sunyata-Emptiness and Allah/God-the Unseen Absolute, respectively.

Sunyata as Emptiness based in the doctrine of Dhamma-about universal order/ natural law and liberation through nirvana-enlightenment. And in Islam salvation through belief in Allah/God as unseen, imageless-mono-theos revealed to Muhammad.

In theistic religions, the divine "is cosmic manifestation as Ontological cause and anthropomorphic personification." And in Buddhism, the Absolute is of as said before an "acosmic and anonymous character ... Niravanic Grace" projected through the Buddhas. ${ }^{57}$ Buddha's Nirvana is a super-rational unveiling of mercy about how to deal with the problem of suffering. ${ }^{58}$ 
The Buddha called this phenomenon dukkha (suffering), whereas the Qur'an refers to man as being created in kabad-struggle and toil or affliction. (Qur'an 90:4)

Through nirvana, the Buddha was liberated from the fetters of suffering (dukkha) and entered a state of relief, peace, and rest. He was freed from confusion, turmoil, anguish, and distress and entered a state of bliss. The Buddha realized the state of being a compassionate arahant (an enlightened human being).

Prophet Muhammad's experience of waby (revelation) liberated him from the suffering rooted in kufr- (ingratitude to and denial of the existence of One Unseen God) and shirk (attributing divinity to other than God).

Each of them defeated the antagonistic forces of evil called mara in Buddhism and shaytan in Islam.

Buddhism and Islam are not only systems of philosophical empiricism, systems of meditation or political theology/doctrine, legal system or ideologies as often portrayed to us. Each of them in their own right offers answer to the basic existential question about what is to be human-to live and to die.

The tradition of the prophets is mentioned in the Qur'an as follows:

The apostle, and the believers with him, believe in what has been bestowed upon him from on high by his Sustainer: they all believe in God, and His angels, and His revelations, and His apostles, making no distinction between any of His apostles; and they say: "We have heard, and we pay heed. Grant us Thy forgiveness, O our Sustainer, for with Thee is all journeys' end! (Qur'an 2:285)

And in The Lotus Sutra in this way:

Shariputra, when the Buddhas of the future make their appearance in the world, they too will use countless numbers of expedient means, various causes and conditions, and words of simile and parable in order to expound the doctrines for the sake of living beings. These doctrines will all be for the sake of the one Buddha vehicle. And these living beings, by listening to the doctrines of the Buddhas, will all eventually be able to attain wisdom embracing all species.

"Shariputra, the Buddhas, the World-Honored Ones, who exist at present in the countless hundreds, thousands, ten thousands, and millions of Buddha lands in the ten directions, benefit and bring peace and happiness to living beings in large measure, these Buddhas too use countless numbers of expedient means, various causes and conditions, and words of simile and parable in order to expound the doctrines for the sake of living beings. These doctrines are all for the sake of the one Buddha vehicle. And these living beings, by listening to the doctrines of the Buddhas, are all eventually able to attain wisdom embracing all species. ${ }^{59}$

\section{EVERY ACT OF DEVOTION WILL BE REWARDED}

The high point of the Lotus Sutra is that every action no matter how small or big will be rewarded. Everyone who has been able to realize the law will be rewarded and attain extinction/salvation and be blessed. 
The similar principle of the reward for every action positive or negative will bear its consequences. I am struck by the near parallels between the two following passages from The Lotus Sutra and the Qur'an.

After the Buddhas have passed into extinction, if persons are of good and gentle mind, then living beings such as these have all attained the Buddha way. After the Buddhas have passed into extinction, if persons make offerings to the relics, raising ten thousand or a million kinds of towers, using gold, silver and crystal, seashell and agate, carnelian, lapis lazuli, pearls to purify and adorn them extensively, in this way erecting towers; or if they raise up stone mortuary temples or those of sandalwood or aloes, hovenia or other kinds of timer, or of brick, tile clay or earth; if in the midst of the broad fields they pile up earth to make a mortuary temple for the Buddhas, or even if little boys at play should collect sand to make a Buddha tower, then persons such as these have all attained the Buddha way.

If there are persons who for the sake of the Buddha fashion and set up images, carving them with many distinguishing characteristics, then all have attained the Buddha way.

Or if they make things out of the seven kinds of gems, of copper, red or white copper,

pewter, lead, tin iron wood, or clay, or use cloth soaked in lacquer or resin to adorn and fashion Buddha images, then persons such as these have all attained the Buddha way. If they employ pigments to paint Buddha images, endowing them with the characteristics of hundredfold merit, if they make them themselves of have other make them, then all have attained the Buddha way.

If someone wit a confused and distracted mind should take even one flower and offer it to a painted image, 
in time he would come to see countless Buddhas.

Or if a person should bow or perform obeisance, or should merely press his palms together, or even should raise a single hand, or give no more than a slight nod of the head, and if this were done in offering to an image, then in time he would come to see countless Buddhas.

And if he himself attains the unsurpassed way and spreads salvation abroad to countless multitudes, he will enter the nirvana of no remainder as a fire dies out when the firewood is exhausted. ${ }^{60}$

In the Qur'an, it is stated in the following two sections:

When Earth is shaken with her (final) earthquake

And Earth yieldeth up her burdens,

And man saith: What aileth her ?

That day she will relate her chronicles,

Because thy Lord inspireth her.

That day mankind will issue forth in scattered groups to be shown their deeds. And whoso doeth good an atom's weight will see it then,

And whoso doeth ill an atom's weight will see it then. (Qur'an Chapter 99: 1-8)

Lo! thy Lord is ever watchful.

As for man, whenever his Lord trieth him by honoring him, and is gracious unto him, he saith: My Lord honored me.

But whenever He tried him by straitening his means of life, he said: My Lord despises me.

Nay, but ye (for your part) honor not the orphan

And urge not on the feeding of the poor.

And ye devour heritages with devouring greed.

And love wealth with abounding love.

Nay, but when the earth is ground to atoms, grinding, grinding,

And thy Lord shall come with angels, rank on rank,

And hell is brought near that day; on that day man will remember, but how will the remembrance (then avail him)?

He will say: Ah, would that I had sent before me (some provision) for my life!

None punishes as He will punish on that day!

None binds as He then will bind.

But ah! thou soul at peace!

Return unto thy Lord, content in His good pleasure!

Enter thou among My bondmen!

Enter thou My Garden! (Qur'an 89:14-30) 


\section{CONCLUSION}

Discussions about Islam and Buddhism are a rare topic today. I am often asked what is common between them or are they even compatible. My answer is always in affirmative.

Today, references to Islam and Buddhist relations are largely made to the Buddhist-Muslim conflicts in the Theravada countries of Sri Lanka, Myanmar, and Thailand, also the discrimination and vulnerability of Buddhist minorities in Indonesia, Malaysia, and Brunei. The Muslim presence in Mahayana countries is miniscule. In these two types of Buddhist countries, Islam is associated with terrorism following the media reporting about the wars in the Middle East and the terrorist events in the West committed by members of the home-grown Muslim communities and Western opposition to them.

There are several reasons for the Muslim abandonment of the study about Buddhism since the medieval period.

First, the decline of Muslim kingdoms in both the Middle East and Southeast Asia due to colonialism and the transformation of local religious landscape into categories of the majorities and the minorities by exiling or making the local Buddhist rajas and Muslim sultans as the custodian of religions as seen in the case of Sri Lanka, Palembang, India, and Myanmar. And limiting the religious instructions in the hands of the traditionally trained clerics and monks who did not benefit or were opposed to modernization.

Today, Southeast Asia is the only geographic region where Islam and Buddhism are the main religions coexisting side by side at the ratio of 42 percent and 40 percent, respectively. In spite of this, there is a dearth of local Muslim and Buddhist scholars of each other's religion. Their interaction is largely restricted to interfaith social activities and dialogues engaged in by community leaders and social activities and not the scholars nor the academic community. ${ }^{61}$

Not aiming to nor seeking to Islamize Buddhism or Buddhicize Islam but learn more about their shared wisdoms in addressing the core question about what it means to be human and what is the end of the meaning of life-a persistent nonresolving question I engage in studying the Buddhist texts to learn the Buddhist answer to it. And I hear many parallels.

The differences between Islam and Buddhism are based in the different cosmological, metaphysical, and geographic origins of the two religions in different human cultural-linguistic zones.

The Buddha was the enlightened One and Muhammad a blessed prophet of mercy for humanity. ${ }^{62}$ Learning about their teachings and wisdoms without preconceived ideas will help overcome the state of ignorance and aversions that currently exist between the Muslims and the Buddhists as violent conflicts lurk in the corner and will arise soon or are already happening.

The Qur'an and the Lotus Sutra are unique texts in their own historical and religious contexts. We can learn from both of them for the benefit of expanding our horizons without prejudices and biases and the parallels in their teaching when 
recognized deeply can enrich us to build an interreligious understanding. The intention here is to learn from each other for building a better world no matter how small a ripple effect it makes.

Dr. Imtiyaz Yusuf is Associate Professor and Deputy Dean for Students Development and Community Engagement and also Coordinator, Islam and Buddhism Program at the International Institute of Islamic Thought and Civilization, International Islamic University Malaysia (ISTAC-IIUM). Dr. Yusuf was formerly Senior Fellow at the Alwaleed Center for Muslim-Christian Understanding, Georgetown University, Washington D.C., USA. He is also the former Director of the Center for Buddhist-Muslim Understanding in the College of Religious Studies at Mahidol University in Thailand.

He specializes in Religion with a focus on Islam in Thailand and Southeast Asia and also Muslim-Buddhist dialogue. Dr. Yusuf has contributed to the Oxford Encyclopedia of Islamic World (2009); Oxford Dictionary of Islam (2003); Encyclopedia of Qur'an (2002); and Oxford Encyclopedia of Modern Islamic World (1995). He was also the special Editor of the The Muslim World - A Special Issue on Islam and Buddhism Vol. 100, Nos. 2-3 April/July 2010.

Dr. Yusufs most recent publications are: Multiculturalism in Asia: Peace and Harmony (2018); “The Nabi-Rasul in Arabian/Semitic Religious Tradition: Qur'anic Monotheism, Prophet Muhammad and the Shaping of Muslim World View" Islamic Studies 58 (4):December 2019 pp. 519-533; "Three Faces of the Rohingya Crisis: Religious Nationalism, Asian Islamophobia, and Delegitimizing Citizenship" in Studia Islamika, [Scopus Indexed], Vol. 25, no. 3, December 2018, pp. 503-542; "Nationalist Ethnicities as Religious Identities: Islam, Buddhism and Citizenship in Myanmar", American Journal of Islamic Social Sciences 34:4 (2017) pp. 100-119); "Islam and Buddhism" in Wiley-Blackwell Companion to Interreligious Dialogue, Catherine Cornille (ed.) (Hoboken, NJ: Wiley-Blackwell, Inc, 2013), pp. 360-375.

NOTES

1. William Theodore de Bary, The Buddhist Tradition: In India, China and Japan, 1st ed. (New York: Vintage, 1972).

2. S. M. Yusuf, "The Early Contacts Between Islam and Buddhism," University of Ceylon Review 13 (1955): 1-28.

3. Imtiyaz Yusuf, "Three Faces of the Rohingya Crisis: Religious Nationalism, Asian Islamophobia, and Delegitimizing Citizenship," Studia Islamika, S.1.], 25, no. 3 (2018): 503-542. ISSN 2355-6145, at http:/journal.uinjkt.ac.id/index.php/studia-islamika/article/ view/8038, accessed May 11, 2019. doi: 10.15408/sdi.v25i3.8038.

4. Donald S. Lopez Jr, From Stone to Flesh: A Short History of the Buddha, Reprint edition (Chicago: University of Chicago Press, 2013).

5. Kieko Obuse, "Theology of Religions in the Context of Buddhist-Muslim Relations," in ASEAN Religious Pluralism: The Challenges of Building a Socio-Cultural Community, ed. Imtiyaz Yusuf (Bangkok: Konrad Adenauer Stiftung, 2014), 72-85.

6. Saddharamapundariksutra in Robert E. Buswell and Donald S. Lopez, The Princeton Dictionary of Buddhism (Princeton: Princeton University Press, 2013), 729-730. 
7. Tomoko Masuzawa, The Invention of World Religions: Or, How European Universalism Was Preserved in the Language of Pluralism, 4/15/05 edition (Chicago: University Of Chicago Press, 2005).

8. S. Radhakrishnan, Eastern Religions and Western Thought (Delhi: Oxford University Press, 1995).

9. Glasenapp, Helmuth von, Buddhism-A Non-theistic Religion, with a Selection from Buddhist Scriptures (New York: G. Braziller, 1970).

10. Edward Sachau, Alberuni's India (New York: W. W. Norton \& Company, 1971).

11. Muhammad Hamidullah, Emergence of Islam: Lectures Delivered at Islamia University, Bahawalpur, 1980, ed. Afzal Iqbal, 1st ed (Islamabad: Islamic Research Institute, 1993); Dr. Muhammad Hamidullah, Muhammad Rasulullah PBUH by Dr. Muhammad Hamidullah (Idara Islamiat, 2017).

12. Muhammad Asad, The Message of the Qur'an (Gibraltar: Dar al-Andalus, 1980), 907.

13. Ibid., 110, 160.

14. Richard C. Foltz, Religions of the Silk Road (New York: St. Martin's Press, 1999).

15. Syed Muhammad Naguib al-Attas, Some Aspects of Sufism as Understood and Practised among the Malays (Singapore: Malaysian Sociological Research Institute Ltd., 1963).

16. Imtiyaz Yusuf, "Islam and Buddhism" in Wiley-Blackwell Companion to Interreligious Dialogue, ed. Catherine Cornille (Hoboken: Wiley-Blackwell, Inc., 2013).

17. Islam was founded in $611 \mathrm{CE}$ when Prophet Muhammad received the first revelation of the Qur'an in Mecca.

18. Encyclopedia of Islam, s.v. "Balkh"; Encyclopaedia Iranica, s.v. "Buddhism."

19. The term Abl al-Kitab, or "the People of the Book," is a Qur'anic term and Prophet Muhammad's reference to the followers of Christianity and Judaism as religions that possess divine books of revelation (Torah, Psalter, and Gospel) which gives them a privileged position above followers of other religions in Arabia. See Encyclopedia of Islam, s.v. "Ahl al-Kitab."

20. Ignaz Goldziher, Introduction to Islamic Theology and Law (Princeton: Princeton University Press, 1981), 141.

21. Quoted in S. M. Yusuf, "The Early Contacts Between Islam and Buddhism," University of Ceylon Review 13 (1955): 28.

22. Richard C. Foltz, Religions of the Silk Road, 100. Also Richard Bulliet, "Naw Bahar and the Survival of Iranian Buddhism," Iran 14 (1976): 140-145.

23. Richard C. Foltz, Religions of the Silk Road, op. cit., 100-101. See also Encyclopedia of Religion, Mircea Eliade, General ed., s.v. "Madrasah."

24. Imtiyaz Yusuf, "Muslim-Buddhist Relations Caught between Nalanda and Pattani," in Ethnicity and Conflict in Buddhist Societies in South and Southeast Asia, ed. K. M. de Silva (Colombo: Vijitha Yapa, 2015).

25. Marshall Hodgson, The Venture of Islam, vol. 2 (Chicago: The University of Chicago Press, 1074), 557.

26. P. J. Zoetmulder, Pantheism and Monism in Javanese Suluk Literature: Islamic and Indian Mysticism in an Indonesian Setting, ed. M. C. Ricklefs (Leiden: Koninklyk Instituut Voor Taal Land, 1995).

27. Alijah Gordon, The Propogation of Islam in the Indonesian-Malay Archipelago (Kuala Lumpur: Malaysian Sociological Research Institute, 2001); Anthony Shih, "The Roots and Societal Impact of Islam in Southeast Asia," Stanford Journal of East Asian Affairs 2 (Spring 2002): 114.

28. Alexander Berzin, "Response to Tehranian," in, Islam and Inter-Faith Relations, eds. Perry Schmidt-Leukel and Lloyd Ridgeon (London: SCM-Press 2007), 256-260.

29. Richard C. Foltz, Religions of the Silk Road, op. cit., 100. 
30. Eric John Sharpe, Comparative Religion: A History (London: Duckworth, 2003), 11.

31. Sheila S. Blair, A Compendium of Chronicles: Rashid Al-Din's Illustrated History of the World (Oxford: Khalili Collections, 1995).

32. Allama Iqbal Poetry (Javed Nama-12) Taseen-e-Gautam (Gautam Budh Ki Taleemat)," at http:/iqbalstudy.blogspot.in/2013/11/javed-nama-12-taseen-e-gautam-gautam_28.html?m=1, accessed July 28, 2015.

33. "He it is Who hath sent among the unlettered ones a messenger of their own, to recite unto them His revelations and to make them grow, and to teach them the Scripture and Wisdom, though heretofore they were indeed in error manifest" (Qur'an 62:2).

34. John L. Esposito, ed., The Oxford History of Islam, 1st ed. (New York: Oxford University Press, 1999).

35. Imran Nazar Hosein, Islam and Buddhism in the Modern World, Revised ed. (New York: Masjid Dar al-Qur'an, 2001); Harun Yahya, Islam and Buddhism (New Delhi: Islamic Book Service, 2005).

36. "so that at the name of Jesus every knee will bow - in heaven and on earth and under the earth - and every tongue confess that Jesus Christ is Lord to the glory of God the Father." (Philippians 2:10-11)

37. Frithjof Schuon, Treasures of Buddhism (Bloomington: World Wisdom Books, 1993), $10-11$.

38. Ibid., 21.

39. Nichiko Niwano, A Buddhist Kaleidoscope: Essays on the Lotus Sutra, ed. Gene Reeves, 1st ed. (Tokyo: Kosei Publishing Company, 2003), 28.

40. Fazlur Rahman, Islam, 2nd ed. (Chicago: University of Chicago Press, 1979); Isma'il R. Al-Faruqi and Lois Ibsen Al Faruqi, The Cultural Atlas of Islam (New York; London: Macmillan: Collier Macmillan, 1986); Huston Smith, Islam: A Concise Introduction, 1st ed. (San Francisco: HarperOne, 2001); Frithjof Schuon and Annemarie Schimmel, Understanding Islam: A New Translation with Selected Letters, ed. Patrick Laude (Bloomington: World Wisdom, 2011); Seyyed Hossein Nasr, The Heart of Islam: Enduring Values for Humanity, 7/18/04 ed (New York: HarperOne, 2004).

41. Niwano, A Buddhist Kaleidoscope, 40-47, 48.

42. Ibid., 49.

43. Ibid. 49.

44. Wilfred Cantwell Smith, What Is Scripture?: A Comparative Approach (Minneapolis: Fortress Press, 1994); Barbara C. Sproul, Primal Mytbs: Creation Myths Around the World (New York: Harper Collins, 2013).

45. Said Lahib As, Recited Koran: A History of the First Recorded Version (Princeton: Darwin Press, 1975); Fazlur Rahman, Major Themes of the Qur'an: Second Edition, 2nd ed. (Chicago: University Of Chicago Press, 2009); Muhammad Asad, The Message of The Qur'an, Bilingual ed (Bitton, Bristol: The Book Foundation, 2003); Bruce Lawrence, The Qur'an: A Biography, 1st ed. (New York: Atlantic Monthly Press, 2007).

46. Bruce B. Lawrence, Shabrastani on the Indian Religion, Reprint 2012 ed. (The Hague: De Gruyter Mouton, 2012).

47. Paul Ricoeur, Time and Narrative, Vols. I-III, Volume 3 ed. (Chicago: The University of Chicago Press, 1990).

48. David Pellauer and Bernard Dauenhauer, "Paul Ricoeur," in The Stanford Encyclopedia of Philosophy, ed. Edward N. Zalta (Stanford: Metaphysics Research Lab, Stanford University, 2016), at https:/plato.stanford.edu/archives/win2016/entries/ricoeur/, accessed May 5, 2019. 
49. Ibid.; Paul Ricoeur, Essays on Biblical Interpretation (Philadelphia: Fortress Press, 1980); Andre LaCocque and Paul Ricoeur, Thinking Biblically: Exegetical and Hermenentical Studies, translated by David Pellauer, 1st ed. (Chicago: University of Chicago Press, 1998); Professor Kevin J. Vanhoozer, Biblical Narrative in the Philosophy of Paul Ricoeur: A Study in Hermeneutics and Theology (Cambridge: Cambridge University Press, 2007).

50. Burton Watson, The Lotus Sutra, Reissue ed. (New York: Columbia University Press, 1993), 19-20.

51. "The Last Sermon Of Prophet Muhammad (SAW)," at http:/www.iium.edu.my/ deed/articles/thelastsermon.html, accessed May 6, 2019.

52. See Upayakauśalya in Buswell and Lopez, The Princeton Dictionary of Buddhism, 182.

53. Fazlur Rahman, Islamic Methodology in History (Islamabad: Islamic Research Institute, 1984), 177.

54. Watson, The Lotus Sutra, xvi-xvii, 26.

55. Ibid., 26.

56. Ibid., 31.

57. Frithjof Schuon, The Treasures of Buddhism (New Delhi: Smriti Books, 2003), 21.

58. Ibid., 10-11.

59. Watson, The Lotus Sutra, 32.

60. Ibid., 38-40.

61. Sulak Sivaraksa and Chandra Muzaffar, Alternative Politics for Asia: A Buddhist-Muslim Dialogue (Petaling Jaya, Selangor Darul Ehsan, Malaysia: International Movement for a Just World, 1999).

62. We sent you (Muhammad) not save as a mercy for the peoples. (Qur'an 21:107) 